\title{
Project Completion Report on China's Room AC Reach Standard
}

\author{
For China Sustainable Energy Program \\ the Energy Foundation
}

\author{
By \\ Jiang Lin \\ Lawrence Berkeley National Laboratory \\ March 2005
}

\begin{abstract}
After much anticipation and hard work, China's reach standard for room airconditioners was announced in September 2004, with the first tier going into effect on March 1, 2005 and the reach standard taking effect on January 1, 2009. This is a major milestone in the development of minimum energy efficiency standards in China: finally China has set a minimum standard that is meaningful and stringent. According to our preliminary analysis, the majority of room ACs products on the Chinese market in 2004 would not meet the 2009 reach standard requirement.
\end{abstract}

In addition to setting the minimum requirement, China's new AC standard also include classification requirement for the newly established Energy Information Label, as well as the certification requirement for CECP's Energy COnservation Label.

Highlights of the 2009 reach standard include:

The Chinese Reach Standard for Room AC in 2009 is tighter than American counterpart, and almost matches the efficiency of American Central AirConditioners

- Summer peak demand reduction in 2020 due to the reach standard exceeds the capacity of the Three Gorges Project.

\section{China's Room Air Conditioner Minimum Efficiency Standard}

The 2005 standard values are shown below:

Room Air Conditioner Minimum Efficiency Standard

The measured value of EER of room air-conditioners must be greater than or equal to the values shown in Table 1. 
Table 1. Energy Efficiency Ratios (EER)

\begin{tabular}{|c|l|c|}
\hline \multirow{2}{*}{ Category } & $\begin{array}{c}\text { Rated Cooling (CC) } \\
\text { W }\end{array}$ & $\begin{array}{c}\text { EER } \\
\text { W/W }\end{array}$ \\
\hline Single-package & & 2.30 \\
\hline \multirow{3}{*}{ Split } & $\mathrm{CC} \leq 4500$ & 2.60 \\
\cline { 2 - 3 } & $4500<\mathrm{CC} \leq 7100$ & 2.50 \\
\cline { 2 - 3 } & $7100<\mathrm{CC} \leq 14000$ & 2.40 \\
\hline
\end{tabular}

\section{Energy Efficiency Grades for the Energy Information Label}

Based on the measured EER value, consult Table 2 to determine the Energy Efficiency Grade of the product.

Table 2 Energy Efficiency Grade specifications

\begin{tabular}{|c|c|c|c|c|c|c|}
\hline \multirow{2}{*}{ Category } & \multirow{2}{*}{$\begin{array}{c}\text { Rated Cooling } \\
(\mathrm{CC}, \mathrm{W})\end{array}$} & \multicolumn{5}{|c|}{ Energy Efficiency Grade } \\
\cline { 3 - 7 } & & 5 & 4 & 3 & 2 & 1 \\
\hline $\begin{array}{c}\text { Single- } \\
\text { package }\end{array}$ & & 2.30 & 2.50 & 2.70 & 2.90 & 3.10 \\
\hline \multirow{3}{*}{ Split } & $\mathrm{CC} \leq 4500$ & 2.60 & 2.80 & 3.00 & 3.20 & 3.40 \\
\cline { 2 - 7 } & $4500<\mathrm{CC} \leq 7100$ & 2.50 & 2.70 & 2.90 & 3.10 & 3.30 \\
\cline { 2 - 7 } & $\begin{array}{c}7100<\mathrm{CC} \leq \\
14000\end{array}$ & 2.40 & 2.60 & 2.80 & 3.00 & 3.20 \\
\hline
\end{tabular}

\section{Energy Conservation Label Specification}

The EER of energy-efficient room air conditioners must be greater than or equal to the values shown in Table 3. 
Table 3. Energy Efficiency Specification

\begin{tabular}{|c|l|c|}
\hline \multirow{2}{*}{ Category } & $\begin{array}{c}\text { Rated cooling (CC) } \\
\text { W }\end{array}$ & $\begin{array}{c}\text { EER } \\
\text { W/W }\end{array}$ \\
\hline $\begin{array}{c}\text { Single- } \\
\text { package }\end{array}$ & & 2.90 \\
\hline \multirow{3}{*}{ Split } & $4500<C C \leq 7100$ & 3.20 \\
\cline { 2 - 3 } & $7100<\mathrm{CC} \leq 14000$ & 3.10 \\
\cline { 2 - 3 } & & 3.00 \\
\hline
\end{tabular}

On 1 January 2009, the reach standard will go into effect, raising the minimum standard as shown in Table 4:

Table 4. Energy Efficiency Ratios (EER) in 2009

\begin{tabular}{|c|l|c|}
\hline \multirow{2}{*}{ Category } & $\begin{array}{c}\text { Rated Cooling (CC) } \\
\text { W }\end{array}$ & $\begin{array}{c}\text { EER } \\
\text { W/W }\end{array}$ \\
\hline Single-package & & 2.90 \\
\hline \multirow{3}{*}{ Split } & $\mathrm{CC} \leq 4500$ & 3.20 \\
\cline { 2 - 3 } & $4500<C \mathrm{CC} \leq 7100$ & 3.10 \\
\cline { 2 - 3 } & $7100<\mathrm{CC} \leq 14000$ & 3.00 \\
\hline
\end{tabular}

The reach standard does not specify the energy efficiency grades or the energy efficiency specification to go into effect at that time.

\section{Energy Savings from the New Standard}

Savings due to this new standard are likely to be $10 \mathrm{TWh}$ of electricity and 2.7 million tons of carbon by 2010, 46 TWh of electricity and 12.3 million tons of carbon by 2020 (Table 5). About $75 \%$ of the expected savings by 2020 stems from the more stringent reach standard to go in effect in 2009. 
The peak demand reduction calculation depends on an accurate assessment of the coincident peak factor for room air conditioners in China. The reductions are likely to be about $4.5 \mathrm{GW}$ in 2010 and $20.4 \mathrm{GW}$ by 2020 . The 2020 peak demand reduction estimate exceeds the $17 \mathrm{GW}$ capacity of the Three Gorges Dam.

Table 5. Expected Energy Savings from the Room Air Conditioner Standard

\begin{tabular}{|c|c|c|c|c|c|c|}
\hline Year & Stock & Shipments & $\begin{array}{l}\text { Energy } \\
\text { Savings }\end{array}$ & $\begin{array}{c}\text { CO2 } \\
\text { Savings }\end{array}$ & $\begin{array}{l}\text { Carbon } \\
\text { Savings }\end{array}$ & $\begin{array}{c}\text { Peak } \\
\text { Savings* }\end{array}$ \\
\hline & millions & millions & million $k W h$ & million tonnes & million tonnes & GW \\
\hline 2000 & 67 & 17.3 & & & & \\
\hline 2001 & 85 & 18.3 & & & & \\
\hline 2002 & 106 & 21.6 & & & & \\
\hline 2003 & 133 & 28.2 & & & & \\
\hline 2004 & 161 & 29.6 & & & & \\
\hline 2005 & 189 & 31.0 & 714 & 0.7 & 0.2 & 0.3 \\
\hline 2006 & 218 & 32.6 & 1,464 & 1.4 & 0.4 & 0.6 \\
\hline 2007 & 248 & 34.2 & 2,251 & 2.2 & 0.6 & 1.0 \\
\hline 2008 & 278 & 35.9 & 3,077 & 3.0 & 0.8 & 1.4 \\
\hline 2009 & 308 & 37.7 & 6,587 & 6.4 & 1.8 & 2.9 \\
\hline 2010 & 337 & 38.5 & 10,166 & 9.9 & 2.7 & 4.5 \\
\hline 2011 & 365 & 39.3 & 13,817 & 13.5 & 3.7 & 6.1 \\
\hline 2012 & 390 & 40.0 & 17,541 & 17.1 & 4.7 & 7.7 \\
\hline 2013 & 414 & 40.8 & 21,339 & 20.9 & 5.7 & 9.4 \\
\hline 2014 & 435 & 41.7 & 25,188 & 24.6 & 6.7 & 11.1 \\
\hline 2015 & 453 & 42.5 & 29,034 & 28.4 & 7.7 & 12.8 \\
\hline 2016 & 469 & 43.3 & 32,837 & 32.1 & 8.8 & 14.5 \\
\hline 2017 & 484 & 44.2 & 36,573 & 35.7 & 9.7 & 16.1 \\
\hline 2018 & 497 & 45.1 & 40,142 & 39.2 & 10.7 & 17.7 \\
\hline 2019 & 510 & 46.0 & 43,360 & 42.4 & 11.6 & 19.1 \\
\hline 2020 & 522 & 46.9 & 46,113 & 45.1 & 12.3 & 20.4 \\
\hline \multicolumn{2}{|c|}{ Cumulative Total: } & 755 & 330,201 & 323 & 88 & \\
\hline
\end{tabular}

\section{International Comparisons}

Although product types and product categories of room air conditioners vary around the world, it is possible to provide a general comparison of China's new room air conditioner standard with those in effect in a number of other countries. In China, the most common room air conditioner is the split, wall-mounted air conditioner of less than $4500 \mathrm{~W}$ power. The following tables are all expressed in EER. 
LBNL-57387

By 2009, China's minimum room AC standards (for single package units) will have surpassed the current US standard and will have reached the current EU "A" level of efficiency for split units.

US and Canada

\begin{tabular}{|l|l|}
\hline window & 2.87 \\
\hline central & 3.37 \\
\hline
\end{tabular}

\section{South Korea}

\begin{tabular}{|l|c|l|}
\hline window & & 2.88 \\
\hline split & $\mathrm{CC}<4000 \mathrm{~W}$ & 3.37 \\
\hline & $4000-10,000 \mathrm{~W}$ & 2.97 \\
\hline & $10,000-17,500$ & 2.76 \\
\hline
\end{tabular}

\section{Singapore}

Window

2.73

Taiwan

\begin{tabular}{|l|l|l|}
\hline window & $\mathrm{CC}<2300 \mathrm{~W}$ & 2.71 \\
\hline & $2300-4100 \mathrm{~W}$ & 2.77 \\
\hline & $\mathrm{CC}>4100 \mathrm{~W}$ & 2.60 \\
\hline split & $\mathrm{CC}<410 \mathrm{~W}$ & 2.97 \\
\hline & $\mathrm{CC}>=4100 \mathrm{~W}$ & 2.73 \\
\hline
\end{tabular}

\section{European Union (labeling)}

\begin{tabular}{|l|l|l|l|l|l|l|l|}
\hline & G & F & E & D & C & B & A \\
\hline window & $<2$ & 2 & 2.2 & 2.4 & 2.6 & 2.8 & $>3$ \\
\hline split & $<2.2$ & 2.2 & 2.4 & 2.6 & 2.8 & 3 & $>3.2$ \\
\hline
\end{tabular}

Japan
\begin{tabular}{|l|l|c|c|}
\hline window & & Heat pump & AC-only \\
\hline & & 2.85 & 2.67 \\
\hline split & & Heat pump & AC-only \\
\hline & CC<2500W & 5.27 & 3.64 \\
\hline & $2500-3200 \mathrm{~W}$ & 4.90 & 3.64 \\
\hline & $3200-4000 \mathrm{~W}$ & 3.65 & 3.08 \\
\hline & $4000-7100 \mathrm{~W}$ & 3.17 & 2.91 \\
\hline & $>7100 \mathrm{~W}$ & 3.10 & 2.81 \\
\hline
\end{tabular}

Note: There is some uncertainty about the accuracy and comparability of Japan's test measurements. 
LBNL-57387

\section{Budget Summary}

LBNL has received US $\$ 75,000.00$ from the Energy Foundation for this project. The project costs at the end of March 2005 is US $\$ 75,000$, with the following breakdowns,

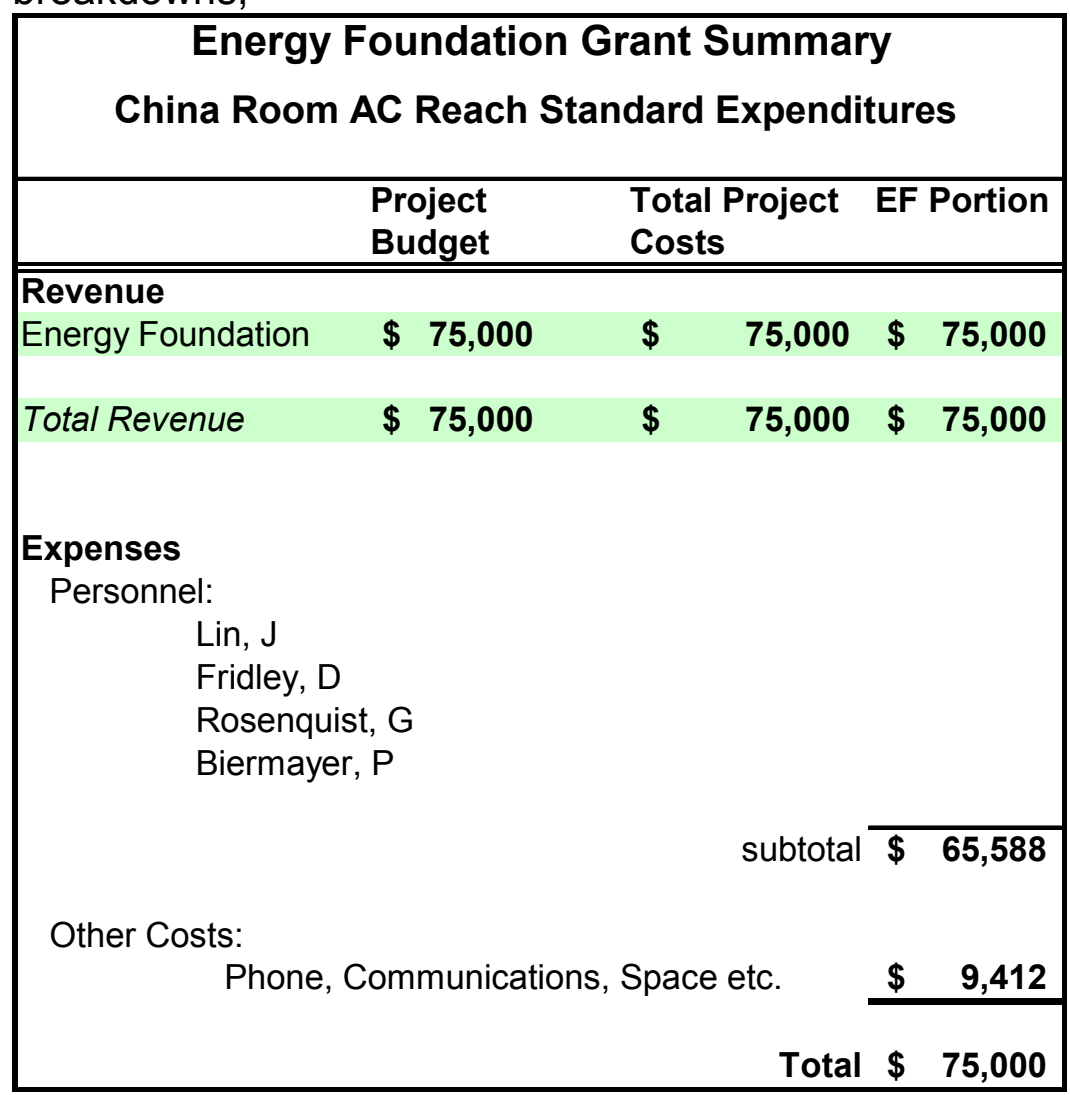

